AP: Ontine Journat in Public Archaeology Volume 6 - 2016 p. 51-74

\title{
Participating in the contingency. Painting, sweeping and cooking
}

Jaime DELGADO RUBIO Postdoctoral fellow of the National Council of Science and Technology (Mexico) at CSIC-INCIPIT (Santiago de Compostela, Spain)

Received: 16/05/16 - Accepted: 09/09/16

\section{Abstract}

The aim of this article is to identify, document and analyse three participatory actions undertaken in Mexico. They offer an alternative ground for analysis and reflection, as they were conducted outside the control of the State, offering the possibility to use different methodologies that contain key elements to think about a reorganization of the existing relation between Institutions and society. Based on extremely simple principles of action (painting, sweeping and cooking) their effects can help reshape the value and use of archaeological heritage in Mexico.

\section{Keywords}

Mexico, participation, archaeological heritage, contingency

As part of my post-doctoral studies in the Institute of Heritage Sciences in Santiago de Compostela (Spain), supported by the CONACYT (Mexico), I had the opportunity to carry out a review of the theory and methodology of some social participation exercises published in the specialized literature. Over the course of this process, the idea of "institutionalized social participation" has been a constant. This form of participation, which occurs within the sphere of the Mexican state administration, has worked as a way of containing actions of differing types, such as consultations, surveys, elections, the transfer of obligations, information and even the evaluation of projects which have already been decided 
upon, omitting the way in which the participants have ended up influencing or changing the direction of government agendas (Tejera 2002).

However, I do not consider this omission to be harmless or innocent, but rather a reflection of the historical resistance of the Mexican state and its institutions to cede power to organized social groups. We believe that behind this omission lies a strategy or policy which, on the one hand, aims to undermine the foundations of intervention, while, on the other hand, calling on diverse sectors of civil society to associate themselves to the process of "civil participation" (Alonso 2016).

Thus, by disabling the participants' ability to make decisions, those in power become victims of their own success as, despite seeing their institutional agendas being advanced, they remove the possibility of other social agents assuming any kind of coresponsibility (at different levels, degrees and intensities) as far as the decisions they could have taken are concerned, thus generating a system of mutual misunderstanding and accusation regarding the implementation of public policy (Delgado 2014).

In order to illustrate this statement, two cases can be cited in which social groups were called upon by the Mexican Instituto Nacional de Antropología e Historia (INAH, National Institute of Anthropology and History) within the implementation framework of the 'Plan de Manejo para la protección de los vestigios arqueológicos en Teotihuacan' (DOS 2010-2015) (Management Plan for the Protection of Archaeological Remains in Teotihuacan) and in Monte Albán, (DOS, 2015) by the INAH's Direction of Sites Operation.

Before examining this issue in detail, it should be pointed out that Teotihuacan and Monte Albán are two of the most important archaeological sites in Mexico, occupying areas of approximately 10 and $20 \mathrm{~km}^{2}$ respectively. In both cases, intervention by the INAH and the federal government led to the expropriation of the respective monumental areas. This was a commendable action but one which left the areas on the fringes of the archaeological sites exposed to the continual urban sprawl, leading to their gradual destruction.

The creation of a participatory management plan for these sites arose from the obligation imposed on the Mexican institutions to 
subscribe to and ratify UNESCO's guidelines for World Heritage Sites. Many of these guidelines have been applied correctly, and many incorrectly, but a basic error in almost all of them has been to conceive social participation under the same criteria which govern the internal operation of an archaeological site (services, administration and infrastructure), without paying attention to the fact that social matters possess their own cultural dynamics, many of which cannot be measured or quantified in management terms. Therefore, social participation has been defined as an extension of the internal operation necessities of an archaeological site than as an exercise in social and democratic negotiation (Delgado 2015).

However, perhaps the most serious problem resulting from the work meetings is that two fundamental differences with the participants have been omitted: ontology and ethics. In the former, some learned institutional managers with knowledge assumed as hegemonic tend to carry out a series of intellectual operations in order to define "the others", imagining an ideal participant who is docile, tame and grateful but, above all, willing to assimilate as quickly as possible the aims and interests of the Administration (González 2014).

In this context, the managers, who are almost always trained in administrative affairs, tend to play down the ontological differences, that is to say, the different ways in which the communities have assumed, given meaning to and taken a position towards so-called "archaeological heritage". This is expressed, for example, when a participant in Teotihuacan states that the sculpture of the feathered serpent, which supposedly represents Quetzalcóatl, is able to communicate with St. Francis of Assisi to ask him for rain. Another example is that of a participant in Monte Albán (Oaxaca), who swears that the medicinal herbs and bushes become stronger and more efficient when they are planted directly on the mounds of ancient pre-Columbian settlements.

In the first case, a small group of participants asked the INAH for authorization to place candles and flowers on the sculpture, while in the second case a request was made to plant Polylepis australis (the tabaquillo tree) on the mounds of the pyramids. The common 
outcome is that the INAH managers choose to ignore these requests or prefer to think that these problems are resolved by mixing these 'beliefs' in appropriate doses with their authorized discourse as, after all, such ontologies may be useful as 'folk' ornaments in their management reports (idem).

In these matters, our opinion coincides perfectly with that of González et al., (2014) and Hernando (2005), in that the impact of capitalist colonialism, with the imposition of a hegemonic powerknowledge balance, has affected different people in the western world to different degrees and on different levels and intensities. However, we would like to add to what the aforementioned authors have stated by saying that, in, the case of Teotihuacan, INAH managers and UNESCO authorities realized that these communities have not remained static, waiting to be absorbed by the dominant culture. Rather, throughout their history, they have assigned different meanings to this information in accordance with their historical, socio-economic and cultural circumstances (Delgado 2013).

A good example of this has been the calculations of cost-benefit which some communities have presented to civil servants and the promoters of institutional projects. This has been the case in Teotihuacan, where the community representatives sat down to negotiate, to then form a kinship network with which they colonized the workforce in the archaeological site. In the case of Monte Albán, the locals have developed a series of strategies for building their houses or businesses within the area of archaeological protection, outside of the guidelines of the INAH. In other cases, such as that of Chilkuntic, in Chiapas (Mexico), violent confrontations between the community and the federal security forces for the control of an archaeological site were the result of political calculation on the part of the community in order to obtain work and subsidies, making the most of their reputation as rebels with the underlying threat of their ability to destabilize the local political system (Villaseñor 2013).

As has previously been pointed out by Cristina Sánchez Carretero (in a personal communication during a meeting of the PARTICIPAT project in February 2016), in cases such as these, it is commonplace that documents like the 1987 Decision Document on the Inscription of the Pre-Hispanic City of Teotihuacan (UNESCO) or the Federal Law on Monuments and Archaeological, Artistic and Historical 
Zones of 1972, become omnipresent in work meetings, having a specific weight which, it is supposed, transcends the participants'. Therefore, when citing these documents, the text is appealed to as yet another participant in the process.

One further problem is of a political nature and is directly related to inequality in the conditions of the process. In this type of participation, and in the name of acting 'horizontally', an attempt is made to eliminate any hint of educational, cultural and economic difference between the participants as a condition for dialogue, thereby hiding any fractures and inequalities which may exist. As mentioned by González Ruibal et al. (2014), this reminds us that the practice of participation acquires a neo-colonial bias, in that the institutional system no longer requires, as it did in the past, a worker or a resource to exploit (as occurred in the colonial age in Mexico). Rather, it desires to build 'responsibilities' and 'capacities' through which a participant, independently of his/her socioeconomic and cultural condition, can be assimilated as quickly as possible to the interests of the state.

In accordance with these conditions and with the participants at the table, some managers may lay out the institutional objectives (mission, vision, management indicators, analyses of strengths and weaknesses, flow charts and other euphemistic elements of 'authority'), after which they proceed to assign particular responsibilities to the participants in a process which we refer to as the "transfer of responsibilities of the state" (Delgado et al., 2014). This is done with the aggravating factor that such agreements are passed on to someone at a superior level in the hierarchy, who eventually assumes the right to accept or reject any agreement reached (Antonio Luis Díaz Aguilar during a PARTICIPAT meeting in November 2015).

Under this way of thinking and doing social participation, many communities across the country tend to ignore, reject, or in some cases use management plans for immediate personal benefits without mediating the notion of a common good or general interest. The rebound of these plans is a testimony that the government's social connectedness continues to be configured as an external prosthesis which has failed to be inserted into the bloodstream of the local. 
56 - Jaime DELGADO RUBIO - Participating in the contingency...

Faced with this scenario, we must ask ourselves whether this is the only methodology available and if there are not alternative social participation exercises with which to address this modus operandi to encourage social participation in cultural heritage.

In order to answer this question, we shall proceed to show three participatory exercises carried out in Mexico which have not yet been documented in the specialized academic literature and which, from our point of view, contain significant elements for reflection and analysis, in the quest for alternative, non-institutionally based, methodologies.

\section{Pintar obedeciendo (Paiting by obeying)}

The first case occurred in the indigenous council of Ricardo Flores Magón de Taniperla in Chiapas (Mexico). The designer and artist Sergio Valdez Ruvalcava, more commonly known as Checo Valdez, a lecturer on the Social Communication degree at the Metropolitan Autonomous University (Universidad Autónoma MetropolitanaXochimilco D.F.), created a mural with the participation of the community, named 'Vida y sueños de la Cañada del Rio Perla' ('Life and Dreams of the Pearl River Valley'). This mural came to be known as the 'Taniperla Mural'. It was revealed at the inauguration of the popular indigenous council of Ricardo Flores Magón on 10th April 1998, in the context of the uprising of the Zapatista Army of National Liberation (EZLN) in Chiapas (Mexico).

The idea for the mural came from a trip Valdez made to Taniperla as a human rights observer. While there, he fell in love with the people and, upon seeing his gift as an artist, the traditional authorities of the area asked him to paint a mural showing significant aspects of the local people's lives. Valdez accepted this task on the condition that the indigenous people would be the ones to actually do the painting. Having been accepted into the assembly of the community, the artist enthusiastically began to prepare everything to be able to begin this participatory process (http://www.jornada. unam.mx/2002/12/15/mas-lara.html). 


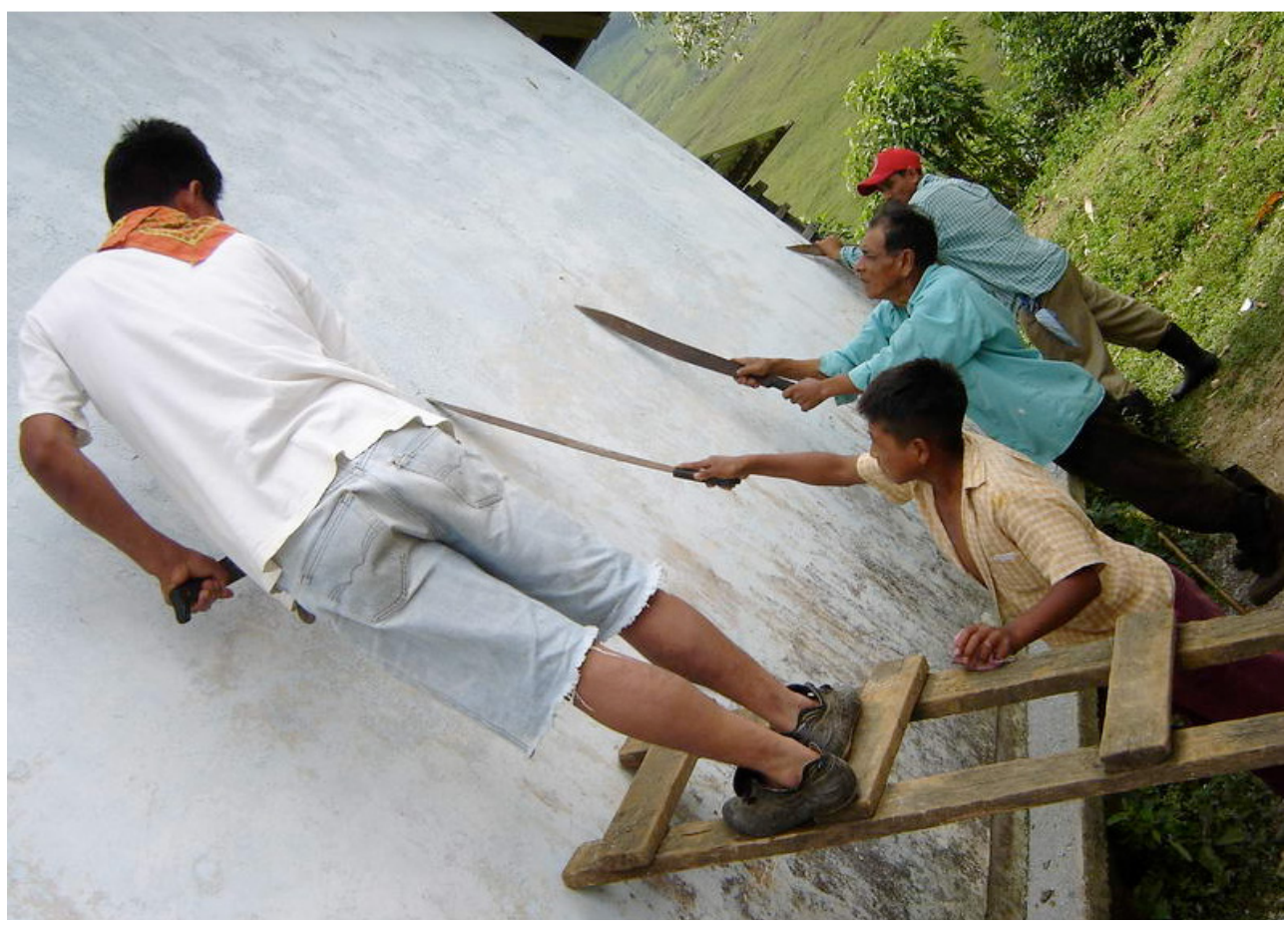

Photo 1: Preparation of the wall. Ricardo Flores Magon, Chiapas, 2008. (Photo: E. Santiago)

The process, named 'Pintar Obedeciendo' (Painting by Obeying), took twelve days to conceive and fifteen to carry out after Valdez and his work group had first learnt the basic concepts of Tzetzal (the local indigenous language). The method they employed consisted of carrying out a survey of the community to find out what themes the indigenous people wanted to be painted in the mural. For this purpose, small papers were distributed, upon which the participants expressed their general ideas. Later, these papers were grouped together into general and specific ideas, which were then used to begin the sketching process.

Each indigenous or mestizo participant came up to the mural using a pencil and colour to express his/her ideas, rather than words, in a decision-making process in which the method and the practice became one act, which the artist named 'participation at the foot of the mural'. During this process, many of the participants claimed 
that they did not know how to draw. However, Valdez reassured them that this inability was not at all important, saying that the quality of the artwork was not essential. What was important was discussion, sharing ideas, interpreting them and then explaining them (Hijar 2011:4).

According to the artist, the quality of the artwork was not judged at any time, neither was any idea rejected. Rather, "the motifs and drawings were the product of a negotiated decision". Regarding this fact, it should be pointed out that, in their rural lives, many of the indigenous people had never used a pencil to draw and had never mixed colours or had the opportunity to express themselves by these means:

One Zapatista comrade boasts that he has painted a star and a sign 'with a corncob'. Another wants the mural to be painted so that her children can see their mother and father in the struggle. Yet another expresses concern for painting native corn, which is in danger from genetically modified crops. (Hijar et al. 2014:5)

The workshop faced several obstacles, including the fact that some of the indigenous people had to leave the mural for a time due to their agricultural obligations, although others continued what had been started. Soon, the number of participants was boosted by the arrival of new artists coming from twelve neighbouring communities. It was from this moment that Valdez came to act as an authority with the full trust of the participants, due to his willingness to work on the co-creation of the artwork and the negotiation of shapes and colours.

According to the data at our disposal, the method worked well, to such a degree that the Pintar Obedeciendo community was divided into external indigenous and mestizo promoters, who succeeded in extending their methodology to 22 communities in the San Jerónimo Tujilá area, producing around 26 community murals in one year and four months. In addition, in 2007, the third edition of the 'Diplomado de Mural Comunitario Participativo' ('Diploma in Participatory Community Murals') took place, with the help of 24 indigenous promoters from the Universidad de la Tierra in San Cristóbal de las Casas, Chiapas (Mexico) (Hijar, et al.2014:5). 


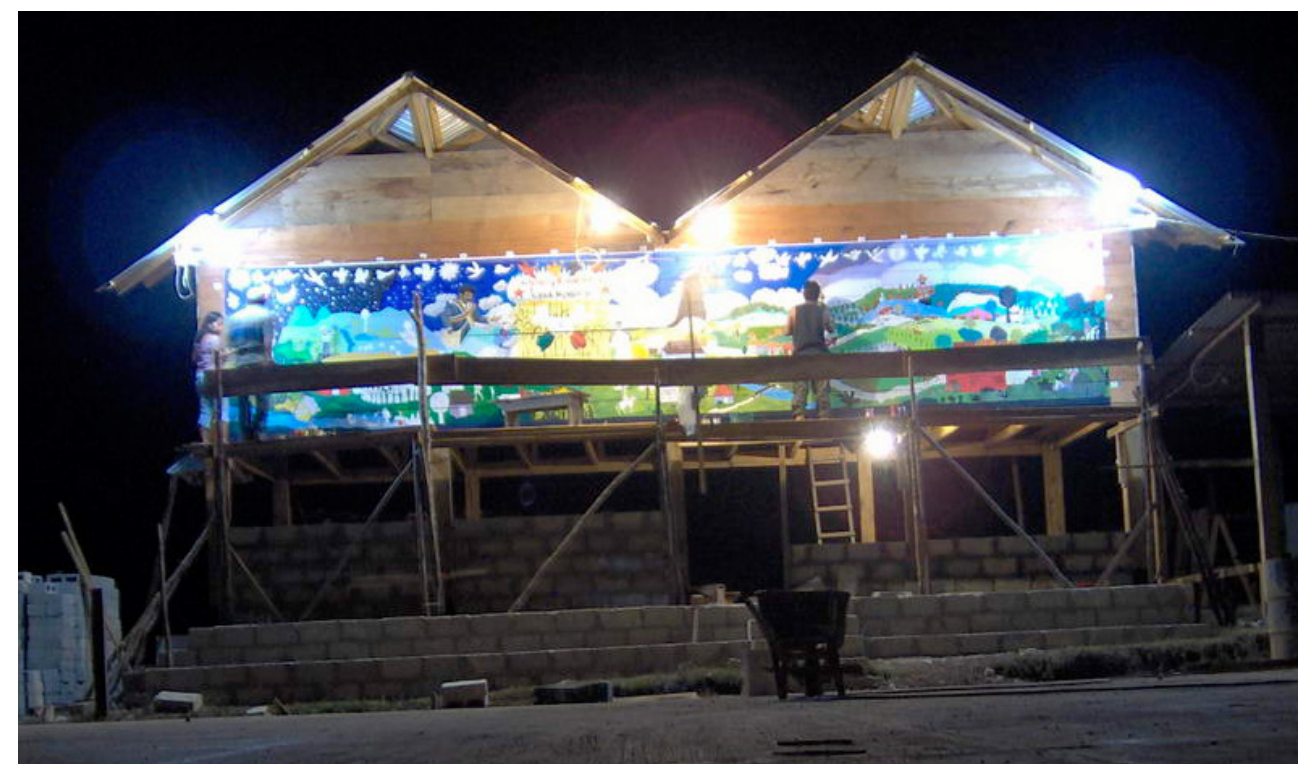

Photo 2: Mural Life and Dreams of Pearl River Glen. Ricardo Flores Magon, Chiapas, 2005. (Photo: Maka)

One of these murals is located in the National School of Anthropology and History, in Mexico City, and was painted by Anthropology students. Another can be found in the Tzotzil indigenous community of Oventic in the Chiapas Highlands, painted on a large canvas measured $10 \times 2 \mathrm{~m}$. This mural was displayed in Paris (France), financed by the Parc La Villette Museum, as part of a two-year exhibition on indigenous people in Mexico (Ripoll http:// www.jornada.unam.mx/2002/12/15/).

This methodology has reached beyond borders, with two murals being painted in Germany (Cologne and Munich), seven in Spain (six in Barcelona and one in Zaragoza), and one in Canada (Toronto). The artist has plans to travel to China in the future, where he has been invited by the Chengdu Academy of Fine Arts to teach the methodology to students of Social Communication and Participatory Art. Furthermore, at the beginning of 2014, a mural will be created in La Lupita, a community of Guatemalan refugees, on the southern Pacific coast in Guatemala (Hijar et al., 2014:6). 


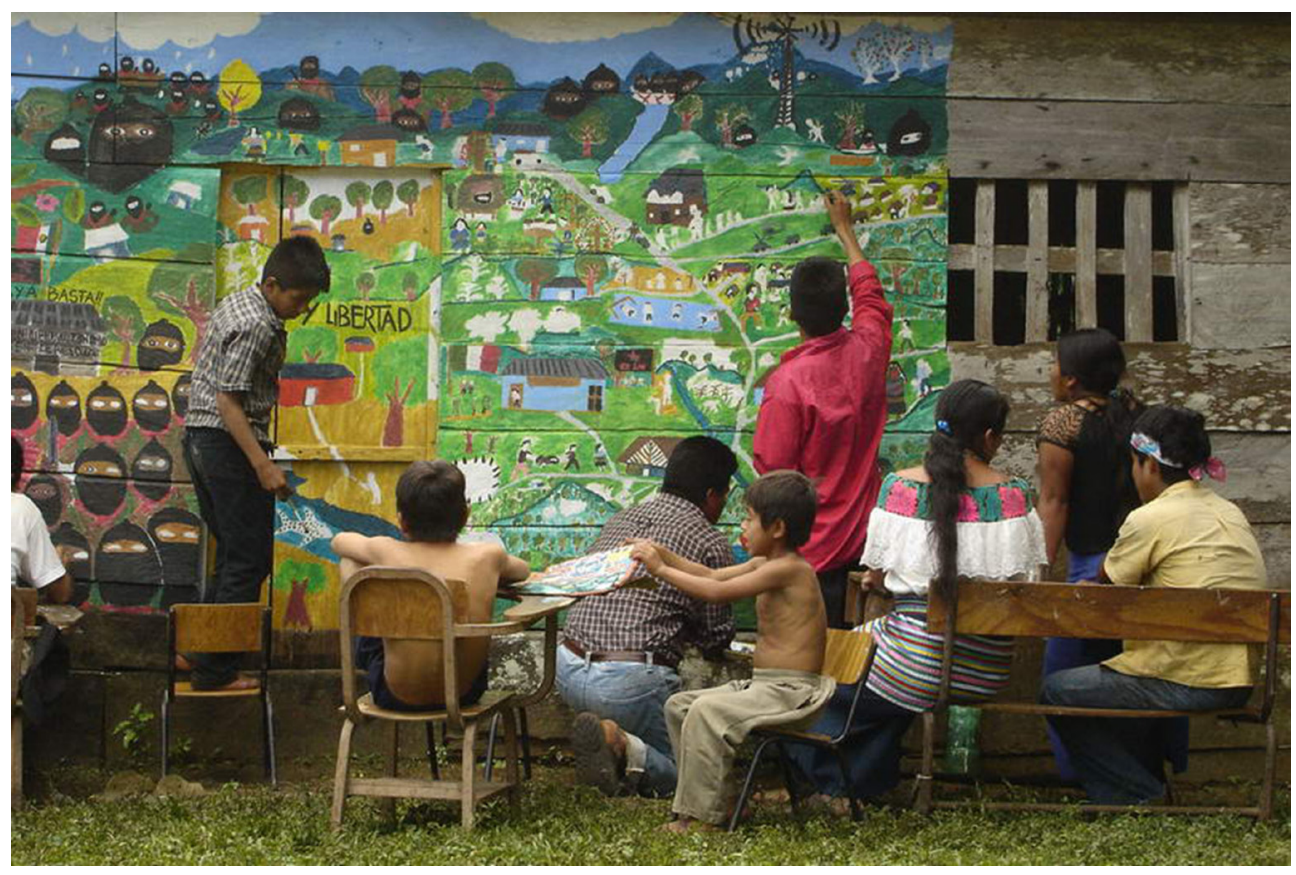

Photo 3: Taniperla and participation at the mural (Photo taken from Hijar et al. 2011)

The participatory mural entitled 'Life and Dreams of the Pearl River Valley' only survived for approximately 44 hours, as it was destroyed in a military police operation, which marked the beginning of the government offensive against the rebel Zapatista municipalities in 1995, which resulted in Valdez and twelve foreigners who were in the town going to prison. However, according to Ana Ruiz Blanch (in a speech given in November 2015 in the Incipit, Spain), the destruction of the mural only succeeded in revitalizing it, as today there are approximately fifty replicas of it all over the world, making it one of the most copied murals in history, thus giving it the name 'El Mural Mágico' ('the Magic Mural'). 


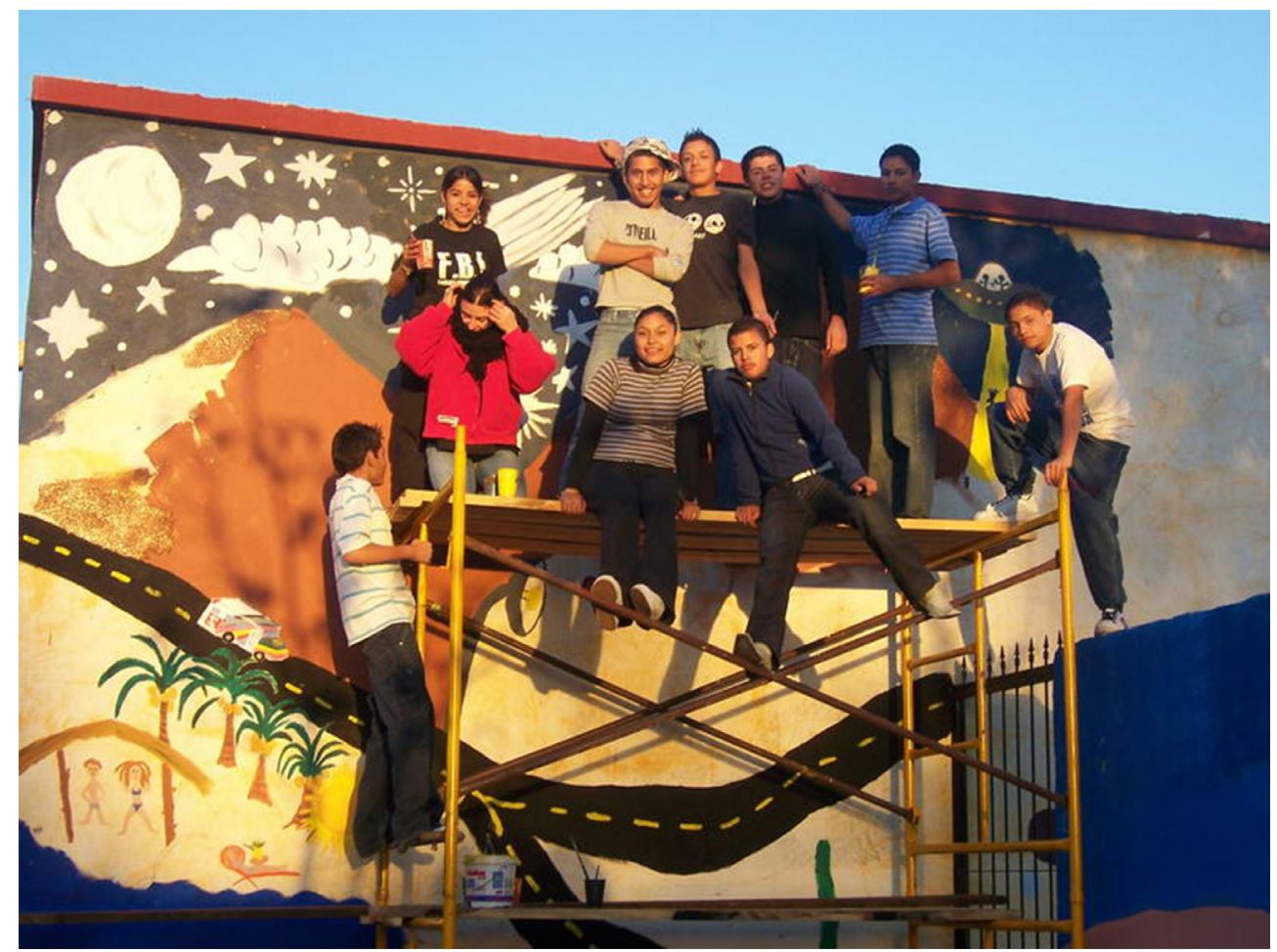

Photo 4: Participatory process. 2008. (Photo: jpascual)

\section{Cleaning up the square}

Another case that is similar in methodology occurred in the Plaza Aguilita in the neighbourhood of La Merced in Mexico City, where a group of academics from the University of Mexico City, led by Joaquín Aguilar, decided to carry out a participatory process based on the extremely simple principle of sweeping up. Joaquín, as everybody calls him, has spent the majority of his career in cultural management, he is by profession a musician and is a native of the popular neighbourhood of La Merced. He knows the codes of the neighbourhood well and, it seems, the neighbourhood knows him. Joaquín and his team set themselves the goal of reviving the square, which, at that time, was abandoned, dark and dirty, constituting a danger for passers-by due to the crimes which took place there. It was in this context that he had the idea of putting a table, a music system, two microphones and two horns, to form a small community radio station (Arvide 2012). 
Over the course of these events, Joaquín faced several obstacles to establishing himself in the square, the most difficult of which was the noise of the powerful loudspeakers of the neighbouring traders, a common characteristic of public places in Mexico City.

I spoke to all of them and said, 'Give me three hours a week. I want to do something for your community, please turn down the volume. Two record sellers understood immediately but one did not. (Arvide et al. 2012:3)

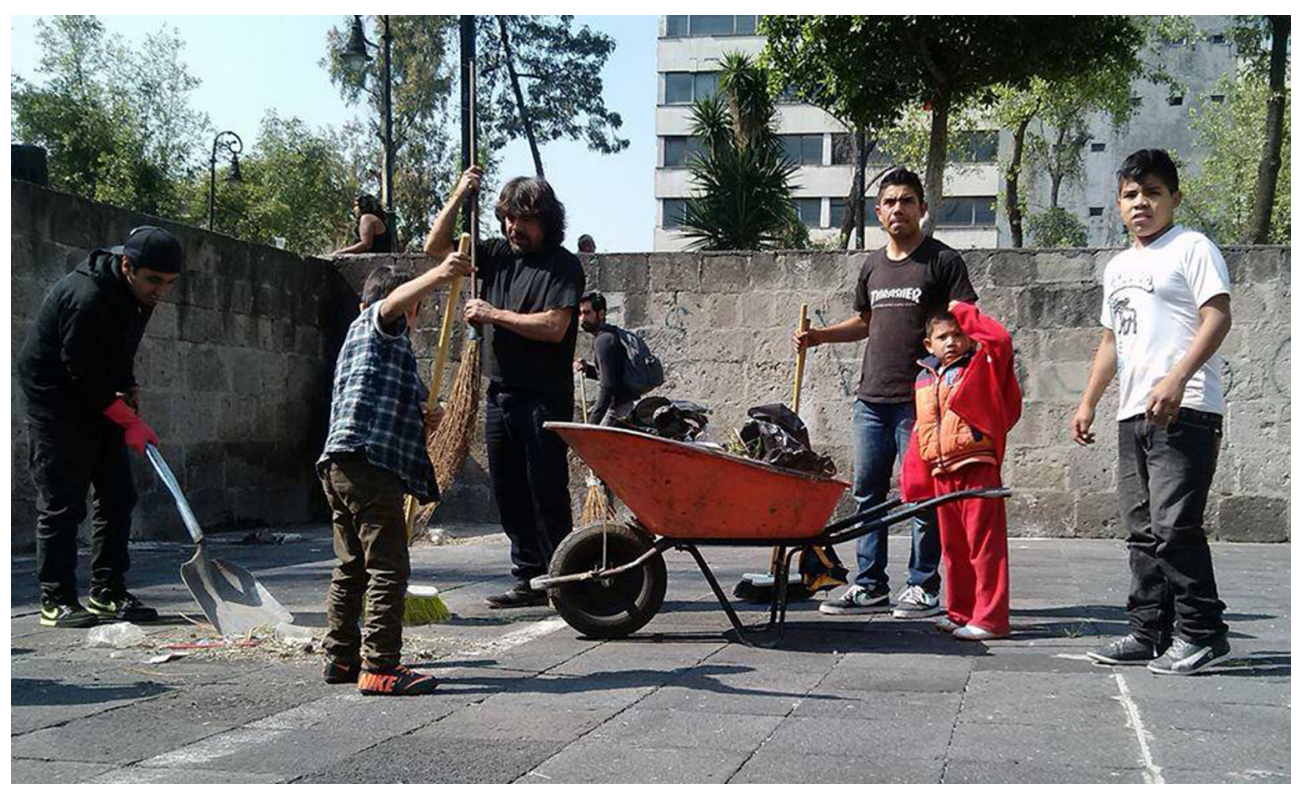

Photo 5: Sweeping up as a means to open up debate in the neighbourhood of La Merced (Photo courtesy of Joaquín Aguilar)

The third record seller ended up doing so and even participating from the project afterwards. Another problem he faced was finding the most appropriate place to set up his radio station. During an interview, Aguilar told us that many of the participatory processes have been the result of circumstances, as, while he was looking for the right place, he realized that the only area available was a small dirty corner, full of excrement and rubbish. So, he decided to clean it up over several days, as a demonstration of his commitment to the idea of reviving the square. 
Soon, the neighbouring tenants were doing the same and even the people frequenting the square were encouraged to pick up a broom and then the microphone for the radio. Since then, every Wednesday, Radio Aguilita calls on passers-by to renew this commitment (from a talk given by Joaquín Aguilar, in the La Merced neighbourhood in Mexico City).

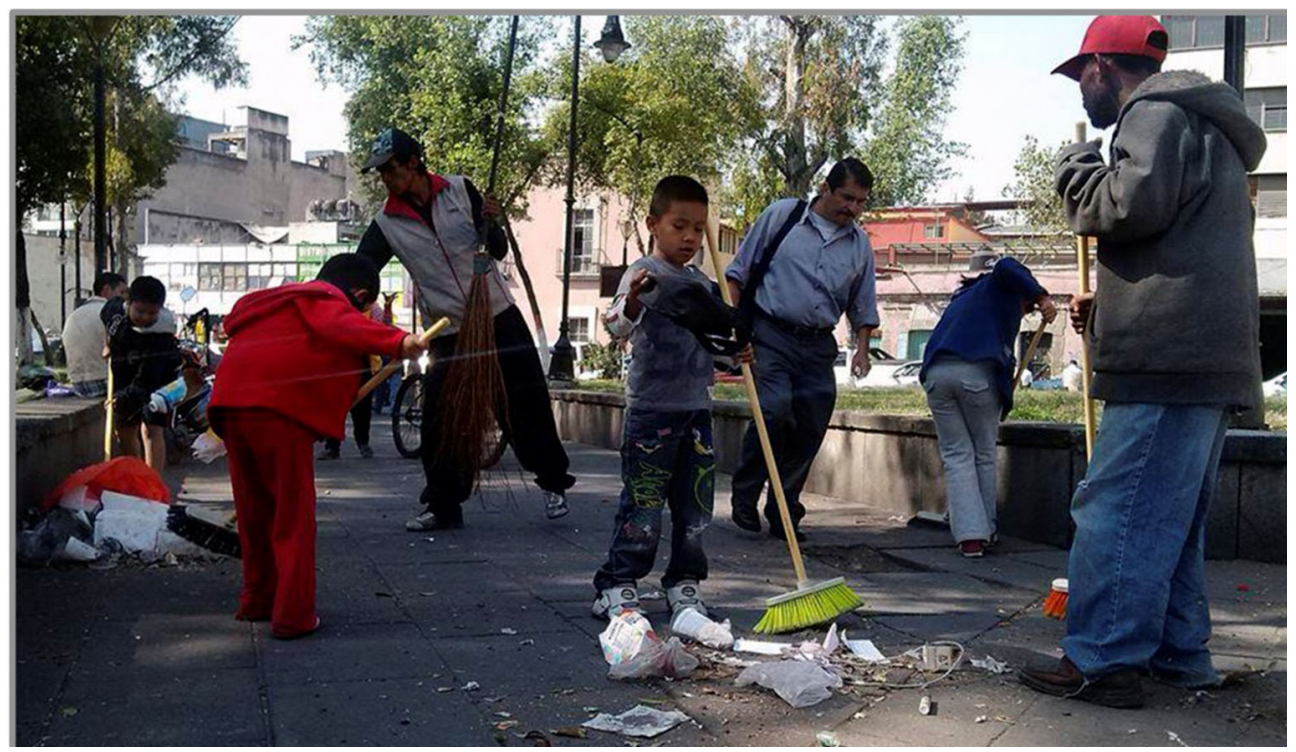

Photo 6: Children, passers-by and homeless people showed a willingness to clean up the public square (Photo courtesy of Joaquín Aguilar)

Thus, over a period of almost six years, the community radio station 'Radio Aguilita' has promoted dynamics of community co-responsibility in inclusive and simple processes. Sweeping up became symbolic of reclaiming the square, acting in an area close to the participant. In other words, it is an activity which everyone can perform as an act of dialogue and participation. With regard to this, Joaquín states:

It's normal that when somebody increases their level of education, they think that they have to start relating to people of that same level but we realized that true social change has to come from below. So, chatting to the lady who comes to do the shopping or the man who sits to read the newspaper in the square, talking to the lads 
64 - Jaime DELGADO RUBIO - Participating in the contingency...

who work in the bars, listening to their problems and solutions has been a process which has opened up the world to an impressive degree, especially to those of us who study Art and Cultural Heritage... It empowers me to generate projects which benefit the neighbourhoods of the city and not only to come to deal with matters on the agenda of governments or of those in power, delegations and ministries (González, Elena 2015:34).

Opening up the microphones of the community radio produced differing effects on the people. It was as if a repressed force had been released and the people were suddenly free to protest, to express their anger, opinions, hopes, complaints and demands, but above all to express all that the neighbourhood means to them and what it means to belong to the neighbourhood. Nowadays, 'Radio Aguilita' has a schedule of programmes for both recognized artistic talents and for improvisation, for those who, after sweeping up, take the microphone in order to say their piece.

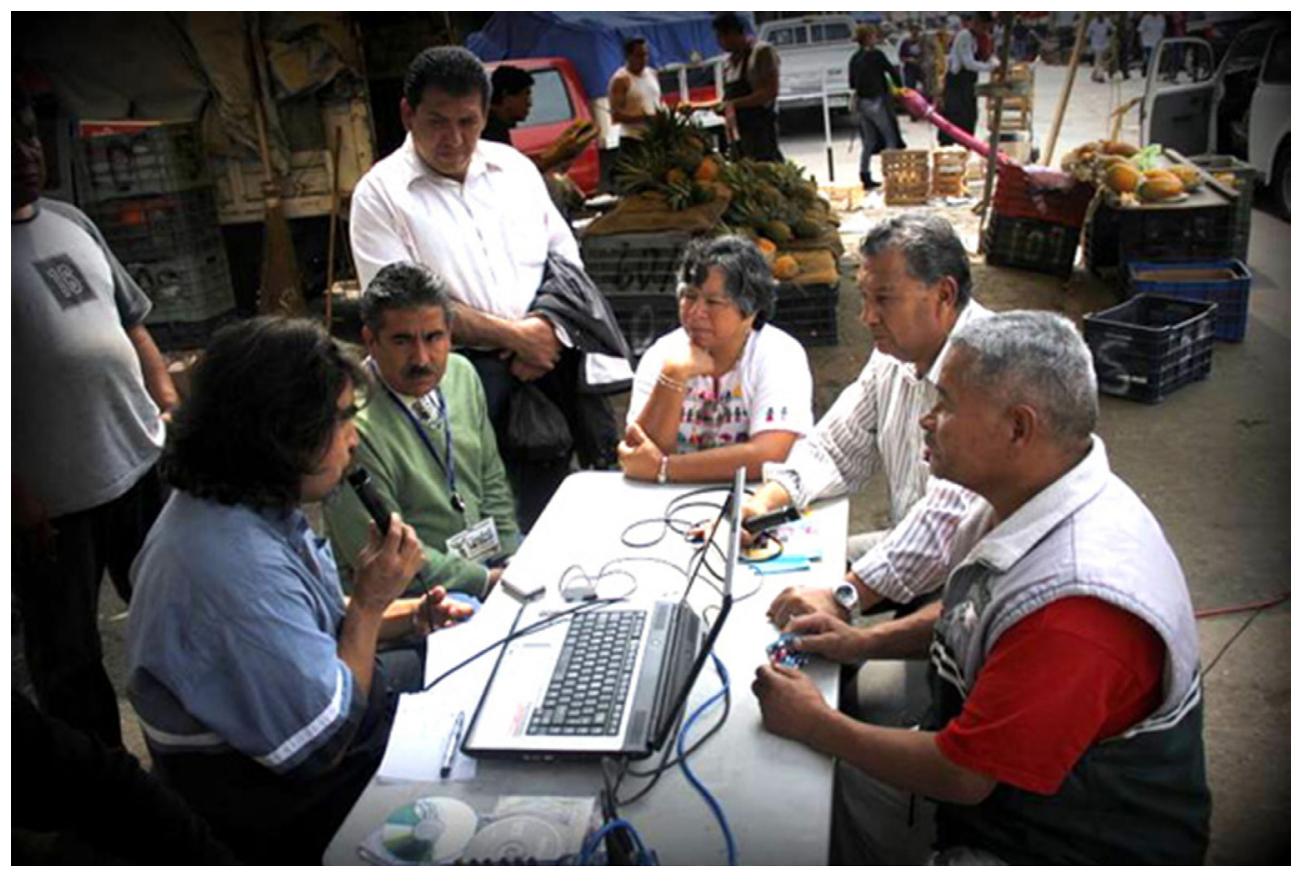

Photo 7: The Aguilita Radio microphones open to neighbors and passersby. (Photo courtesy of Joaquín Aguilar) 
With what has been presented here, we note that the Barrio de la Merced, like many other places in the world, experiences gentrification travelling at different speeds and intensities, so the question here is whether the recovery of the Plaza Aguilita documented here, may inadvertently contribute to the substitution and displacement of indigenous peoples to the advantage of people from other places with greater economic means, who see in the valorisation of the square an investment and business opportunity.

Joaquin Aguilar notes that gentrification as a socioeconomic phenomenon is as real as the local resistance in the neighbourhood: sweeping the square and opening up community radio to neighbours and passers-by are symbols that play in favour of the claims of the neighbours, who in some cases have already started to open new businesses and new services emulating the style and form of other gentrified ones, but retaining the seal of the neighbourhood and offering better prices. Joaquin has termed this phenomenon 'Ingentrificación', which means the reintegration of the local community within the phenomenon of gentrification that is expanding in the historical centre of Ciudad de Mexico.

\section{Cooking rice}

'Las Patronas' are a group of fourteen female volunteers from the community of La Patrona, located in Guadalupe, in the municipality of Amatlán de los Reyes, in the state of Veracruz. For more than 17 years, they have offered food and aid to Central American migrants who board the train known as 'La Bestia', which takes them to the border with the United States. As the train is moving, these women provide aid to the migrants by throwing supplies to them, mainly bags of pre-cooked rice and water, but also oranges, beans, fruit, and clothing (http://www.jornada.unam.mx/ultimas/2015/02/14/).

As their leader, Leónila Vázquez, tells it, this initiative began the day that she and her daughter went to the shop and, on their way home, they saw La Bestia go by. The migrants on the train begged them for food so they threw the contents of their baskets to them. Later, Leónila held a meeting with her friends in order to tell them what had happened, and they decided to make this a regular task. 
She later explained that one woman provided the rice, another the beans, another the tortillas and yet another the bags to contain the supplies (Aspe 2015). She recalled that, on that occasion, only 25 packages were made up, which was not nearly enough.

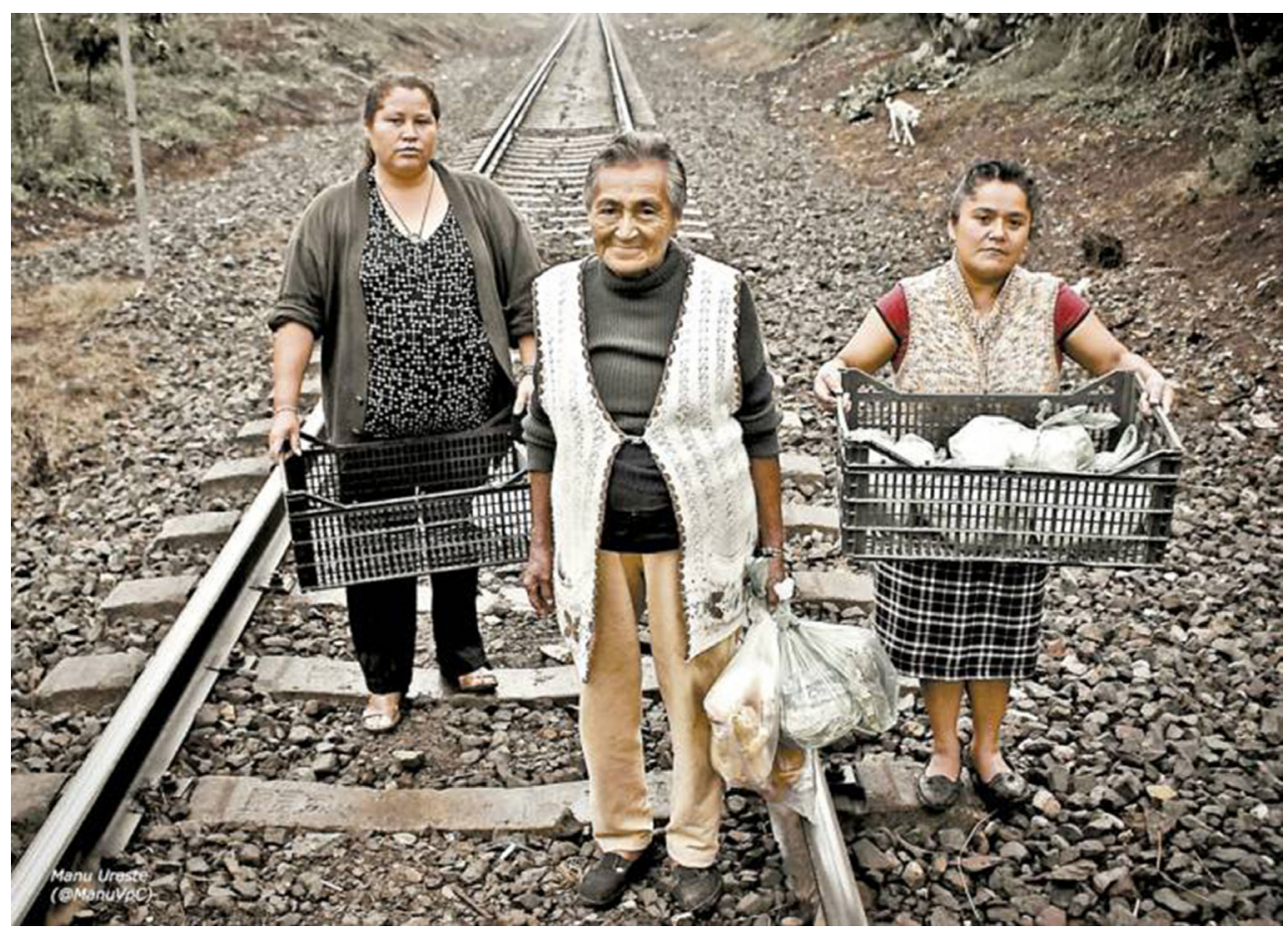

Photo 8: 'Las Patronas' waiting for the train, with Leónila Vázquez in the foreground (Photo taken from www.animalpolitico.com).

From that moment on, 'Las Patronas', as they were already known among the migrants, decided to multiply their efforts. Today, they prepare more than 100 parcels per day, filling bags of rice, washing and filling up plastic water bottles and tying up the parcels for distribution.

We started to give out food in that way, but we did not imagine that it would grow to such a degree. Now, we do not only make food, we also give talks to university students who invite us and, thanks to them, we have received a lot of support (Aspe et al. 2015:12). 
In July 2014, the Mexican president, Enrique Peña Nieto, launched a programme named Frontera Sur (the Southern Border Program), with the official aim of providing protection for the migrants who cross the country. However, the reality is a different story; the militarization of the Mexican border with Central America and the placing of checkpoints, sentry boxes and operatives on the train have all been measures aimed at impeding the progress of migrants towards the United States.

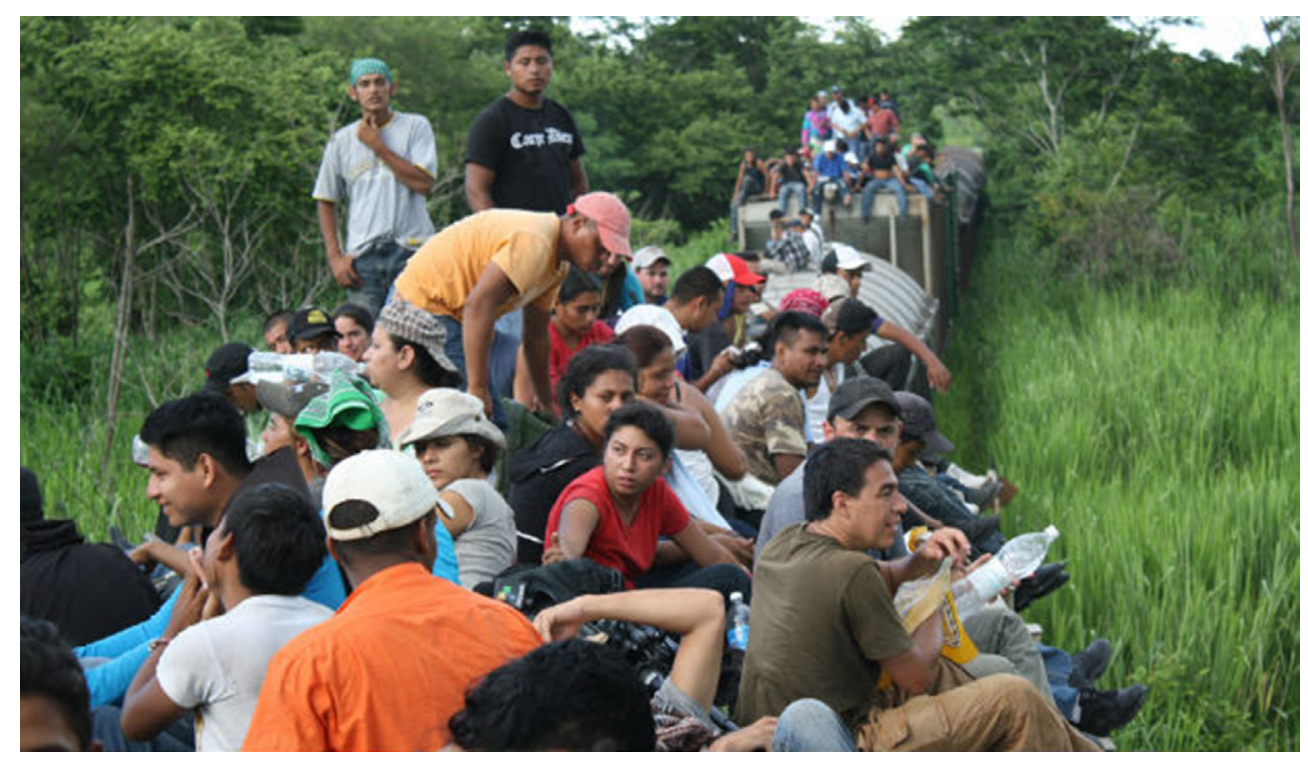

Photo 9: Central American Migrants on board of 'La Bestia', moving towards the border with the United States (Photo taken from diariolavozdelsureste. com).

To give an idea of the scope of this government programme, it should be pointed out that the Secretary of Foreign Affairs, Claudia Ruiz Massieu, at a conference held at the Woodrow Wilson Center in the United States, recognised that, as a result of the programme, the number of migrants detained has tripled, from 65,000 to 200,000 . However, migrants continue to choose to travel on 'La Bestia', despite the increased risk to their integrity, whilst the Foreign Minister receives congratulations from the United States government (eleconomista.com.mx/2015/12/14/canciller). 
While these events occur, 'Las Patronas' carry on cooking, taking care of the situation on the ground, stirring up consciences and provoking the mobilization of different sectors of Mexican society. All of this points towards the hypothesis of the archaeologists Sánchez, González and Picazo, regarding the fact that 'maintenance activities', such as sweeping up and cooking, which have traditionally been carried out by women and which, for centuries, have been considered inferior, unpaid, uninsured activities, have played a crucial role in the processes of political transition by reflecting changes in the economic and social conditions of past and present societies (Sánchez 2007).

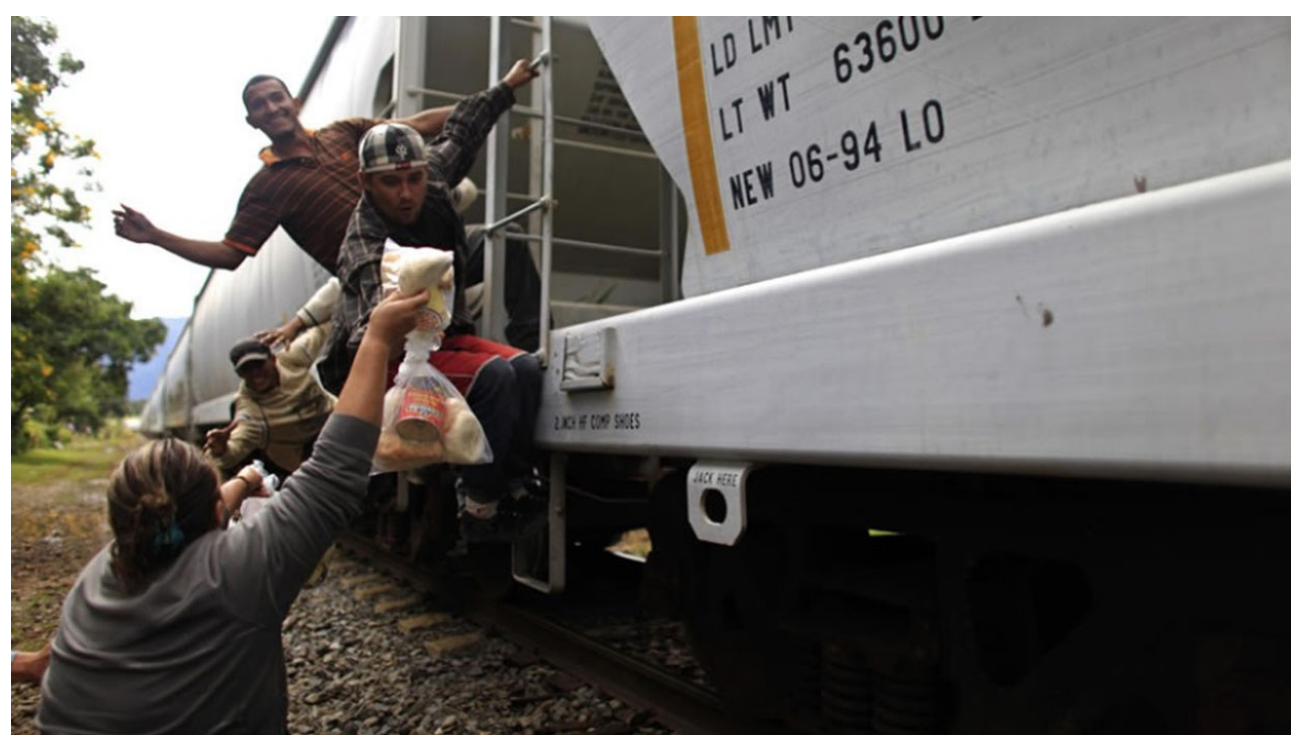

Photo 10: 'Las Patronas' handing out bags of food to migrants (Photo taken from http://e-veracruz.mx/nota/2013-12-15).

This initiative has received both national and international attention and a large number of groups have expressed the desire to take part in this project. Leónila claims that many university students and even business owners have offered their help. When this occurs, she takes them to the kitchen to cook because, she says, it is only there that they can begin to understand the project. 
However, we must not deceive ourselves by thinking that these activities are just to provide help or charity. Rather, it must be understood that this is an initiative which has undergone an unexpected process of political growth, forcing these women to set themselves other goals, such as the establishment of networks and dissemination and participation activities, and the promotion of collective awareness.

This work took them to Spain, where they attempted not only to share their experiences, but also to provoke reflection and discussion regarding the violation of the human rights of migrants in places such as Ceuta and Melilla:

The solution is not to reinforce borders because rivers always follow their course. Migrants will pass wherever they can. Reinforcing borders will only succeed in making the migrants take more risks, leading to more violence, more death and more violations of their rights (Aspe, et al. 2015:5).

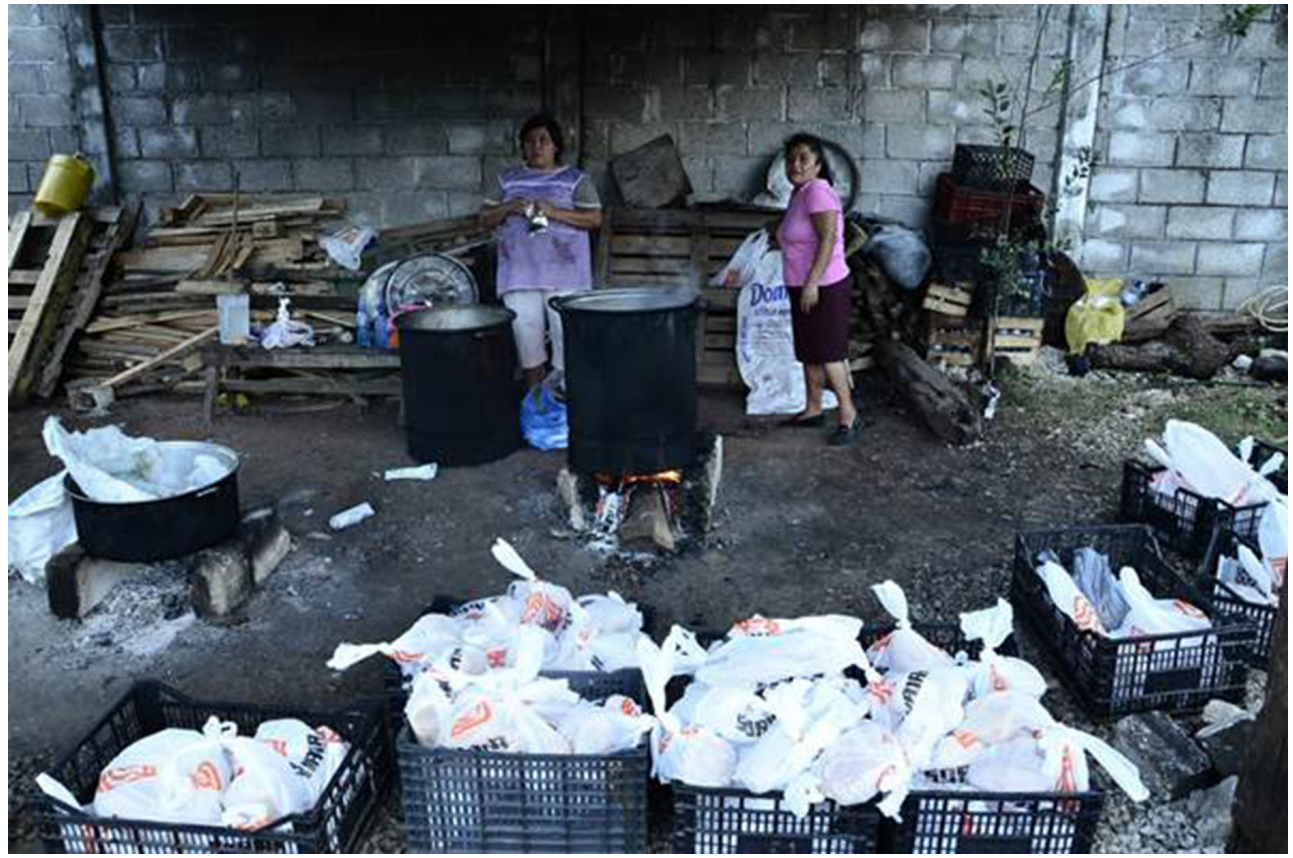

Photo 11: The kitchen as the empirical component of social mobilization. (Photo: http://e-veracruz.mx/nota/2013-12-15) 
70 - Jaime DELGADO RUBIO - Participating in the contingency...

A campaign on change.org succeeded in collecting more than 50,000 signatures in support of the women's work and they have been awarded the National Prize for Human Rights in 2013 (Premio Nacional de Derechos Humanos (México), https://es.wikipedia.org/ wiki/Premio_Nacional_de_Derechos_Humanos_(M\%C3\%A9xico), received a nomination for the Princess of Asturias Award for Concord, and have received the help of a large number of both Mexican and foreign volunteers (http://www.jornada.unam.mx/ /2015/02/14/).

\section{Discussion and conclusions}

First of all, it should be noted here that the three documented cases are translated as social micro scale actions with important elements of reflection and analysis ahead of the search for alternative methodological issues related to social participation. Below is a reading of these:

1. They contemplate an epistemic authority: In these cases, Checo Valdez, Joaquín Aguilar, and Leónila Vázquez, built up an 'authority' during the process, albeit not a legal authority given by decree, but rather an epistemic one, founded on legitimacy and the networks of trust built up amongst the participants themselves (Alonso 2013).

\section{They differentiate between participating and calling}

for participation: In all three cases, the call for participation was made after the fact, immediately after the work had begun, giving people the freedom to decide whether they wanted to participate or not and how and to what degree they wished to do so. This is clearly different to the method employed by the government, in which there is an authoritative theoretical approach and a prior designation of tasks and obligations for participants.

3. The selection of the appropriate means: The managers of the projects leave their field of expertise, placing themselves in an area of development which is close to the participants by carrying out common shared activities which can be performed by anyone as a symbol of integration. 
In these cases, sweeping, cooking rice or painting are the specific references that the participant is contributing to the process, a situation different from the institutional model where participants are mere passive consumers of the institutional decisions taken a priori.

4. The micro-social scale: Carrying out simple actions at a specific time and place with a clear and precise objective. In other words, if someone suggests participation in an attempt to resolve great regional academic problems, it is highly likely that the range of the proposal will escape from the participant's area of development (where they experience their relation with cultural heritage), thus reducing people's confidence when it comes to joining in the effort.

5. They define what they want to negotiate and what they want to defend: In the three cases described here, Sergio Valdez, Joaquín Aguilar and Leónila Vázquez sought interaction with 'others', in the hope that processes of dialogue and negotiation would lead to mutual transformation. This is clearly different to wanting to direct the relationship, as is characteristic of the institutional model, and differs from the way of thinking in postmodern Anthropology, which does not wish to influence others for fear of instilling them with 'the burden of western anthropological values'.

6. They dilute the idea of return. In all three cases, the paternalistic idea of material and symbolic benefit to the community has been deactivated in favour of participation. Action is taken to promote a multi-directional resolution of a common problem, under the understanding that, in the end, everyone involved in the system will benefit both materially and symbolically.

7. They give visibility to the problems. In the three cases shown here, no attempt is made to hide the differences and inequalities which may exist. Rather, they are used as elements upon which a common and shared cause is built. Sweeping, cooking and painting are visible and concrete contributions of each of the participating elements. 
Above all, we consider that the true contribution of these actions, which constitutes the real focal point of this paper, is the fact that they displace what is NECESSARY in order to put what is CONTINGENT at the centre of the realm of possibility.

In light of these facts, contingency is understood as a problem that arises unexpectedly, generating an individual or collective reaction that challenges state control and aims to correct or restore the effects of public policy that affect a community, in whole or in part, and in some cases leading to rethink their relationship with government authorities.

Therefore, without trying to idealize these demonstrations, it is clear that the contingency arises as a social response to a problem that governmental action, or inaction, cannot solve, ending up affecting the interests of communities.

Having said this, we can establish that contingent participation is a social phenomenon closely interwoven and dependent on government action, functioning as the front and back of the relationship between government and society. In response, new questions arise: What are the limits and possibilities of the microsocial scale when trying to institutionalize it? Should we do it from the three experiences shared here? Or would it distort them?

This will be the subject of another trial, but it should be clear by now that social participation in the INAH should neither be an instrument of assimilation of villagers into institutional dynamics, nor a field of postmodern relativism, but a dialogic relationship. This kind of relationship is built on the premise that practical action that triggers greater participation and that the social agent is perfectly capable of deciding how to work with the specialist synergies, institutions and the State, provided it has the political conditions to do so (White 2004).

Therefore, INAH, a body which by law is responsible to research, preserve and disseminate the archaeological heritage in Mexico, should not perceive horizontality as a risk, but explore the need to build bridges between public policy and neighbourhood movements, analyzing the bond and equity participation, with the ultimate aim of providing an empirical basis upon which to propose alternative 
models of wealth management. Hopefully these exercises can open the discussion on this issue.

\section{Acknowledgments}

The work for this paper was carried out with the support of the Mexican National Council of Science and Technology (CONACYT) and the Institute of Heritage Sciences (INCIPIT) of the Spanish National Research Council (CSIC). I would like to thank Ana Ruiz Blanch, Joan Roura and Alfredo González Ruibal for their comments and suggestions and, especially, Felipe Criado Boado for his encouragement.

\section{References}

Alonso, P. 2016. Between certainty and trust: boundary-work and the construction of archaeological epistemic authority. Cultural Sociology 10(4), 483-501.

Aspe, M. 2015. Visita a las patronas en Orizaba Veracruz. In Seminario problemas actuales de México, Universidad Autónoma de Sinaloa, Mexico.

Arvide, C. 2012. Aguilita la radio de un barrio histórico. Boletín Sin Embargo, Casa de la cultura de Talavera, No.16 editorial, Universidad de la Ciudad de Mexico.

Delgado, J. 2013. Movilidad comunitaria y patrimonio arqueológico en México, Colección Ciencia Nueva de la UNAM.

Delgado, J. 2014. Nepantla y patrimonio arqueológico en México. Ruta Antropológica, del posgrado del Instituto de Investigaciones Antropológicas de la UNAM. Mexico.

Delgado, J. 2015. ¿Que son los estudios de factibilidad en México? (primera parte), Tercera Semana de la Arqueología en León, protección conservación de defensa del patrimonio arqueológico. Editorial Motea y Universidad de Meridiano. Mexico.

DOS. 2010-2015. Plan de Manejo de Teotihuacán. Informe para dictamen de la UNESCO, in Archivo Técnico de la Zona Arqueológica de Teotihuacán, Mexico. 
74 - Jaime DELGADO RUBIO - Participating in the contingency...

DOS. 2015. Plan de Manejo de Monte Albán. Informe de avances a la UNESCO, in Archivo Técnico de la Zona Arqueológica de Teotihuacán, Mexico.

González, E. 2015. "Radio Aguilita". Revista Periscopio. El observatorio del Centro Histórico 7.

González, A. 2014. "Malos Nativos" una crítica de las arqueologías indígenas poscoloniales. Revista de arqueología, Vol. 7 No.2 especial VI TAAS.

Hernando, A. 2006. Arqueología y Globalización: el problema de la definición del "otro" en la posmodernidad. Complutum 17, 221-234.

Hijar, C. 2011. Pintar obedeciendo, Mural Comunitario participativo. Revista digital CENIDIAP septiembre 2011.

Sánchez Romero, M. 2007. Arqueología de las mujeres y de las relaciones de género. Complutum 18, 185-194.

Tejera, H. 2002. Las contradicciones sociales de la ciudadanía. Ed. Taurus. Mexico.

Villaseñor, I. 2013. El valor intrínseco del patrimonio cultural ¿una noción aún vigente? Revista Intervención No. 3. Sep. INAH, CONACULTA. 